\title{
Financial Liberalization, Currency Substitution and Savings in Nigeria: Evidence from Cointegration and Error Correction Modeling
}

\author{
Meshach Aziakpono \\ Department of Economics and Economic History, Rhodes University
}

Sanmi Babatope-Obasa ${ }^{1}$

Department of Economics, National University of Lesotho

\begin{abstract}
The study set out to test the McKinnon-Shaw proposition that financial liberalization will significantly increase savings mobilization. The results partly supported the financial liberalization proposition. Variables that capture the effects of currency substitution such as the interest rate differential, a proxy for underground economy, the inflation differential (as a measure of macroeconomic instability) and a dummy for political instability were significant in their adverse impacts on the saving mobilization process in Nigeria. We, therefore, advocate for an active monetary policy that will help manage the delicate balance between domestic and foreign interest rates. This should be combined with macroeconomic policies that create a stable economic environment along with appropriate financial and exchange rate policies, in order to discourage economic agents from preferring foreign denominated assets to those held in the domestic currency.
\end{abstract}

JEL G10, 20

\section{INTRODUCTION}

In the last two decades, we have witnessed large-scale financial sector reforms in many African countries. A major emphasis of these reforms was, inter alia, the need to adopt financial liberalization measures to establish more open credit markets, achieve flexible and eventually freely determined interest rates and enhance financial intermediation (CBN, 1993).

The original theoretical analysis, which provided a rationale for financial liberalization, as a means to promoting financial development and hence economic growth, was given by McKinnon (1973) and Shaw (1973). Their models focus specifically on financial repression in the form of ceilings on 
deposit and/or loan interest rates. Independently and in a rigorous way they highlighted the dangers of financial repression and argued the case for financial liberalization. Their argument is based on the premise that real interest rates influence growth in the economy through their effects on savings and investment, under the implicit assumption that prior saving is required for investment. Though the McKinnon and Shaw frameworks are based on different transmission mechanisms by which real interest rates affects savings, investment and growth, they both agree on the general impact of financial repression and the need to liberalize financial markets. McKinnon's position, often referred to as the complementarity hypothesis, states that since economic agents have to accumulate money balances (or save) before investment can take place, money and physical capital are essentially complementary. Since the real deposit rate of interest positively influences the rate of accumulation of money balances (or saving), interest on deposits will encourage investment. His argument was based on two assumptions: that all investment is self-financed, and that investment expenditure is more indivisible than consumption (Gibson \& Tsakalotos, 1994).

On the other hand, Shaw takes a debt intermediation view. According to Shaw, financial liberalization will lead to an increased role for financial intermediaries. Since financial intermediaries are able to reduce the costs associated with intermediation between savers and investors through economies of scale, risk diversification, liquidity management and so on (see Levine, 1997 for a detailed discussion of these and other channels), they can offer savers more attractive deposit accounts - including higher interest rates and better liquidity- and lenders will get lower borrowing rates. Thus, investment and savings would be encouraged and as a result, economic growth promoted.

The policy implication of the McKinnon-Shaw proposition is that ceilings on interest rates, and, more generally, other government regulations, which prevent the loan market from operating competitively, should be removed.

Empirical evidence on the prediction is mixed. While some studies have found a positive and significant relationship between savings and real interest rates, others have obtained insignificant, and sometimes negative relationships (see Gibson and Tsakalotos, 1994 and Aziakpono, 1999 for a survey of the literature). In discussing financial liberalization models, and also in their testing, it is frequently the case that no clear distinction is made between financial savings and total saving. Often the two are treated as synonymous. As demonstrated in Aziakpono (1999) this is wrong. Also, often no account is taken of the leakage from the formal financial system. Perhaps, more importantly, most tests of the financial liberalization hypothesis give no consideration to the phenomenon of currency substitution, which is prevalent in 
many developing countries that have adopted financial liberalization (Nissanke \& Aryeetey, 1998: 38). Aziakpono (1999) has argued in his analytical review of the theoretical and empirical relationship between financial liberalization, savings and currency substitution that in countries with currency substitution, the interest rate, per se, may not be the only crucial variable in the process of financial liberalization. Other determinants, such as the differential between domestic and foreign interest rates, macroeconomic stability and exchange rate may prove very crucial for the success of financial liberalization. In this paper we provide further evidence on the issue. Specifically, we advance the argument in Aziakpono (1999) by empirically exploring the relationship between financial liberalization, savings and currency substitution using quarterly data between 1980 and 1998 from Nigeria.

The rest of the paper is organized into five sections. Section two provides some facts about the Nigerian economy. Section three reviews the literature on the relationship between financial liberalization, currency substitution and saving. In Section four we provide the framework for the empirical analysis. Section five contains empirical results, and we conclude with Section Six.

\section{SOME FACTS ON THE NIGERIAN ECONOMY}

\subsection{Financial sector reforms}

As part of the Structural Adjustment Programme (SAP), the Nigerian government, in 1986, initiated a large scale restructuring of the financial system. In general, according to Oresotu (1992), the financial sector reforms could be conveniently classified into three categories: reforms for the improvement of the financial structure, reforms designed to improve monetary management, and reforms to strengthen capital movements and the foreign exchange market. We briefly highlight the first two here.

\subsubsection{Reform of the financial structure}

A major policy thrust was directed at the expansion of the financial sector. There was a deliberate effort to encourage the emergence of new institutions and the expansion of existing ones. In the banking sub-sector, the procedure for licensing new banks was eased. As a result, the number of commercial banks rose rapidly from 28 in 1985 to 66 with over 2358 branches, at the end of 1993. The number of merchant banks rose even faster, from 12 in 1985 to 53, with 124 branches, at the end of 1993. As a measure to protect banks with an inadequate capital base, the Nigerian government raised the minimum paid-up capital of commercial and merchant banks to N50 and N40 million, respectively 
(CBN, 1993). Efforts were also made to recapitalize insolvent banks and solve the problem of non-performing assets, in order to restore confidence in the banking system. Moreover, to ensure safe and sound banking, prudential guidelines and strengthened banking supervision were put in place to minimize the occurrence of non-performing assets. An important element of the prudential guidelines consisted of bringing capital adequacy ratios in line with international standards, and allowing provisions for non-performing assets.

\subsubsection{Monetary policy reform}

Initial steps adopted included the rationalization of credit controls. The sectorspecific credit distribution targets were streamlined with a view to giving banks great discretion in the sectoral allocation of credit. A major monetary policy measure was the deregulation of interest rates, which was carried out in stages. The initial gradual upward shifts in bank lending rates were followed by changes in the minimum rediscount rate (MRR). For instance, the MRR, which was fixed at 15 per cent in August 1987, was reduced to 12.75 per cent in December of the same year. During the same period, the saving deposit rate of commercial banks, on the average, was 11.5 per cent and the interest rate paid by merchant banks on 90-day funds was 15 per cent. The prime lending rates of commercial and merchant banks were, on the average, 18.0 and 20.5 per cent respectively, while their corresponding maximum lending rates were 19.2 and 22.0 per cent. Following the need to moderate monetary expansion in 1989, the MRR was raised to 13.25 per cent (Oresotu, 1993).

Another policy element in the determination of interest rates was the fixing of the spread between the saving deposit rates and the prime lending rate as well as the margin between the prime and the maximum lending rates. Subsequently, the spread between the saving deposit rates and lending rates was fixed at seven percentage basis point. Also, the margin between the prime and the maximum lending rates for each bank was fixed at 400 basis points, while the inter-bank rates were to be at least 100 basis points below the prime lending rates.

In 1991, the CBN fixed a maximum spread of 400 basis points between the cost of funds of commercial and merchant banks and their lending rate. The banks were also directed to observe a maximum lending rate of 21 per cent and a minimum deposit rate of 13.5 per cent. However, the ceiling on interest rates was removed in February 1992. This policy was renewed in 1993.

Some measure of regulation was reintroduced into interest rate management in 1994 because of the wide variation and high rates observed following complete deregulation (Oresotu, 1993). Deposit rates were set at 12 to 15 per cent per annum, while a ceiling of 21 per cent was fixed for lending. However, the 
changes in interest rate management were significantly different from what prevailed during the era of regulation. First, the new policy allowed for a band within which deposit interest rates could be negotiated. Secondly, lending rates, unlike in the past, were not specified for activity sectors. Negotiation up to a limit of 21 per cent per annum was allowed for.

\subsection{Response of selected macroeconomic and financial indicators}

\subsubsection{Financial savings}

Financial savings grew in the years following the financial reform measures. Between 1980 and 1986 before the reform measures were introduced, the stock of financial savings (SFS) stood, on average, at 1.4 per cent of the GDP annually. With the adoption of the reform measures (1987-1994) the SFS rose to an annual average of 2.8 per cent of the GDP, a 100 per cent growth rate in comparison to the previous period (1980-1986). The deregulation of interest rates appears to have encouraged the rapid growth in financial savings. As can be seen from Table 1, the deposit rate (savings) averaged 15.53 per cent per year between 1987 and 1994 compared to the period between 1980 and 1986 (prior to reform), when the interest rate on savings averaged just 7.93 per cent.

\subsubsection{Gross national savings and the leakage}

Gross national saving (GNS) is gross domestic income net of consumption. When compared with the response in financial savings, GNS recorded a higher growth rate during the period of reform. The difference was accounted for by the leakage from the formal financial sector, which also experienced a tremendous growth during the period of the reform, as can be seen from Table 1. Hence, while the economic reforms of the SAP era may have brought about increased national savings, much of the savings was held outside the formal financial system. A closer look at the figures in the table show that the proportion of domestic savings held outside the formal financial system increased further during the reform era. For instance, before the reforms, the share of the leakage in total savings was about 70 per cent, while that of financial savings was about 18 per cent. However, with the reforms in place, the share of the leakage rose to 80.4 per cent, while that of financial savings rose to 19.6 per cent.

One of the macroeconomic variables associated with changes in the policy regime was inflation. As can be seen from the table 1, inflation was sporadic during the period of reform, which provided a very unstable macroeconomic environment. Also, the exchange rate of the Naira in relation to other major currencies depreciated significantly during the period. While the official 
exchange rate may indicate a moderate depreciation, the prevailing rates were far lower than the declared official rates. These developments may lead to the phenomenon of currency substitution, a subject we turn to next.

Table 1 Selected macroeconomic and financial indicators

\begin{tabular}{|c|c|c|c|c|c|c|c|c|c|}
\hline \multirow[t]{2}{*}{ YEAR } & \multirow[t]{2}{*}{$\begin{array}{c}\text { SFS/ } \\
\text { GDP } \\
\%\end{array}$} & \multirow[t]{2}{*}{$\begin{array}{c}\text { FFS/ } \\
\text { GDP } \\
\%\end{array}$} & \multirow[t]{2}{*}{$\begin{array}{c}\text { GDS/ } \\
\text { GDP } \\
\%\end{array}$} & \multirow[t]{2}{*}{$\begin{array}{c}\text { LE/ } \\
\text { GDP } \\
\%\end{array}$} & \multirow[t]{2}{*}{$\begin{array}{c}\text { EX } \\
\text { RATER }\end{array}$} & \multirow[t]{2}{*}{$\begin{array}{c}\text { INF } \\
\text { RATE } \\
\%\end{array}$} & \multirow{2}{*}{$\begin{array}{c}\text { SAV. } \\
\text { DEP. } \\
\text { RATE } \\
\%\end{array}$} & \multicolumn{2}{|c|}{$\begin{array}{c}\text { LENDING } \\
\text { RATE } \\
\%\end{array}$} \\
\hline & & & & & & & & Prime & Max \\
\hline 1980 & 3.2 & 11 & 22 & 18.8 & .5464 & 9.9 & 6 & 7.5 & 9.5 \\
\hline 1981 & 6 & 13 & 11 & 9.5 & 0.61 & 20.9 & 6 & 7.75 & 10 \\
\hline 1982 & 8 & 15 & 8 & 2 & 673 & 7.7 & 7.5 & 10.25 & 1.75 \\
\hline 1983 & 3.4 & 17 & .3 & 2.9 & 724 & 23.2 & 5 & 10 & 11.5 \\
\hline 1984 & 2.4 & 17 & 4.2 & 1.8 & 765 & 39.6 & 9.5 & 12.5 & 13 \\
\hline 1985 & 2.1 & 17 & 5 & 3.3 & 894 & 5.5 & 9.5 & .25 & 11.75 \\
\hline 1986 & 1.9 & 19 & 2.1 & -4.0 & 021 & 5.4 & 9.5 & 0.5 & 12 \\
\hline 1987 & 4.4 & 17 & .3 & -1.1 & 018 & 10.2 & 14 & 17.5 & 19.2 \\
\hline 1988 & 3.2 & 16 & 9.6 & 6.5 & 537 & 8.3 & 4.5 & 16.5 & 17.6 \\
\hline 1989 & 0.3 & 11 & 26.7 & 26.5 & 7.392 & 40.9 & 6.4 & 26.8 & 24.6 \\
\hline 1990 & 2.2 & 11 & 28.9 & 26.6 & 8.038 & 7.5 & 18.8 & 25.5 & 27.7 \\
\hline 1991 & 2.5 & 12 & 22.2 & 19.7 & 9.91 & 13 & 14.29 & 20.01 & 20.8 \\
\hline 1992 & 3.1 & 10 & 13.4 & 10.3 & 17.299 & 44.5 & 16.1 & 29.8 & 31.2 \\
\hline 1993 & 4.1 & 12 & 6.4 & 2.3 & 22.051 & 57.2 & 16.66 & 36.09 & 39.06 \\
\hline 1994 & 2.8 & 12 & 3.6 & 0.9 & 21.886 & 57 & 13.5 & 21 & 21 \\
\hline 1995 & -0.04 & 5 & -3.6 & -3.6 & 67.66 & 72.8 & 12.61 & 20.18 & 20.79 \\
\hline 1996 & 1.0 & 5 & 5.8 & 4.8 & 81.253 & 29.3 & 11.69 & 19.74 & 0.86 \\
\hline 1997 & 1.5 & 6 & 9.8 & 8.7 & 1.649 & 15.1 & 4.8 & 3.54 & 23.32 \\
\hline 1998 & 1.3 & 8 & -5.7 & -7.0 & 83.807 & 7.9 & 10.04 & 18.36 & 21.41 \\
\hline \multicolumn{10}{|c|}{ AVERAGE } \\
\hline 1980 & 1.4 & 15 & 7.8 & 5.5 & 04 & 16.02 & 7.93 & 9.68 & 1.36 \\
\hline 1987 & 2.8 & 12.6 & 14.3 & 11.5 & 11.891 & 33.76 & 15.53 & 24.15 & 2.55 \\
\hline 1995 & 0 & 6 & 1.6 & 0.73 & 92 & 31.2 & 9.79 & 17.96 & 21.6 \\
\hline
\end{tabular}

Note: The leakage (LE) is the difference between GNS and SFS (LE = GNSSFS). The SFS is the difference between the flow of financial savings of the current year and that of the previous year $\left(\mathrm{SFS}_{\mathrm{t}}=\mathrm{FFS}_{\mathrm{t}}-\mathrm{FFS}_{\mathrm{t}-1}\right)$.

ER is the nominal exchange rate of the Naira to US Dollar.

Source: Central Bank of Nigeria (1998) 


\section{CURRENCY SUBSTITUTION: CONCEPT AND IMPLICATION ON SAVINGS}

El-Evian (1988) defined currency substitution as a phenomenon in which foreign-currency-denominated money has replaced, either wholly or in part, domestic money in serving as store of value, medium of exchange, and unit of account. This reflects the individual's attempt to protect the value of his or her wealth in the context of deteriorating economic and financial conditions that adversely affect the return on holdings of domestic money relative to those on foreign-currency-denominated money balances, as well as changes in the political and institutional environments that influence expectations regarding the absolute and relative liquidity of domestic and foreign currency denominated assets.

Currency substitution covers a wide variety of possibilities, such as holding foreign currency deposits in the domestic financial system, foreign money held abroad by domestic residents and foreign currency notes circulating within domestic boarders (Hussain, 1996). According to Hussain (1996) currency substitution can be grouped into two types: The first is the formal component, which includes authorized foreign currency bank deposits in the domestic financial system. The second is the informal component, which comprises the unauthorized holding of foreign exchange inside and outside the country.

In developing countries, which are often affected by currency substitution, it is often the case that the formal and the informal components co-exist and interrelate. Foreign fiat money is observed to shift between these components, with the direction and magnitude of change depending on the macro-economic and political environment. If the macro-economic and political environment is perceived to be unstable, foreign exchange tends to shift from formal foreign currency deposits to the black market and household hoarding. Capital flight, which is normally financed by drawing on foreign exchange bank deposits and/or foreign fiat money circulating in the black market, will also increase. This will tend to reduce savings held in the normal financial system (financial savings). If the environment is perceived to be stable, the shifts will be reversed, reducing the size of the black market and household foreign exchange hoarding and encouraging the return of capital, which will tend to increase financial savings (Ramirez-Rojas, 1985). Thus, irrespective of movements in interest rates, financial savings are affected by factors promoting currency substitution.

Foreign currency deposits, the black market for foreign exchange, foreign exchange hoarding by households and capital flight all originate from the general lack of credibility of the overall macroeconomic policy, ultimately reflected in a lack of confidence in the domestic currency. These phenomena, as 
noted by Hussain (1996) are often associated with successive devaluations of the official exchange rate, inadequate real interest rates, the existence of capital controls and rampant inflation caused by excessive money supply or excessive government expenditure.

Many developing countries have experienced that growth in the black market for foreign exchange and foreign currency hoarding outside banks actually force the authorities to grant residents the right to hold foreign currency deposits in the domestic financial system. But, as experience has also shown, foreign currency deposits in the domestic financial system are under greater control by the authorities than the foreign fiat money hoarded outside banks, or the foreign currency deposits held as accounts abroad. Thus, as pointed out by Hussain (1996), granting residents the right to open foreign currency deposits in the domestic financial system often fails to eradicate the black market for foreign exchange, or contain capital flight.

As long as the fundamental factors that encouraged currency substitution (such as macroeconomic and exchange rate instability) remain uncorrected, foreign currency deposits are unlikely to contain the informal component of currency substitution or offset and prevent outflows of hard currency. The holders of foreign currency deposits in the domestic financial system usually have the right to withdraw the amount deposited in the same foreign currency as the initial deposit, which represents a potential leakage (outflow) to foreign countries or to the domestic black market.

Empirical investigations of the impact of currency substitution on savings have not been carried out for many developing countries. A few exceptions include Egypt (Hussain, 1996 and El-Evian, 1988); Yemen Arab Republic (El-Evian, $1988)^{2}$ and Argentina, Mexico, and Uruguay (Ramirez-Rojas, 1985). Hussain's (1996) results are particularly striking. These reveal that a strong negative relationship exists between the variable that is used as a proxy for currency substitution (interest rate differential and inflation rate differential) and saving (both financial and domestic savings).

\section{ANALYTICAL FRAMEWORK}

In this section, we are interested in examining how financial saving; total saving and the leakage react to a given set of determinants, with special reference to the role of the real interest rate. The three models are specified thusly:

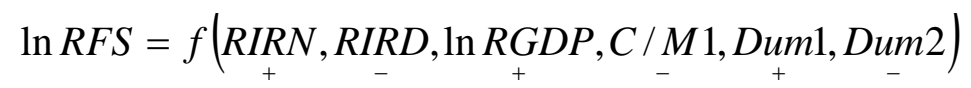




$$
\begin{aligned}
& \ln R L E=f\left(R I R N, R_{+}, C_{+}\right. \text {M1, Dum1, Dum2) } \\
& \ln G N S=f\left(R_{-I_{+}}, I_{-}, I_{+}, \ln _{+}, \operatorname{Dum}_{-}\right)
\end{aligned}
$$

where In denotes the natural logarithm of the relevant variable. The definition and measurement of variables are provided in the Data Appendix.

\subsubsection{Financial saving function}

The financial saving function (equation 1) is expressed as a function of the real interest rate, the real interest rate differential, real income, a proxy for underground economy and two dummy variables. It is expected that financial savings (FS) will be positively related to real income ( $R G D P$ ). This is based on Keynes' absolute income hypothesis, in which the average propensity to save rises with per capita income. It is also positively related to the real rate of interest ( RIRN ) in line with the financial liberalization argument. Because of the important role played by currency substitution (especially the informal component) and capital flight in the Nigerian economy, an attempt is made to estimate the effect of these factors on financial savings. This is done by including, as an independent variable, the differential between the real interest rate in Nigeria (RIRN) and real interest rate in the United States of America (RIRUS ), that is, RIRD . A similar variable was used in Hussain (1996) for the case of Egypt. Since substitution between domestic currency and foreign currency deposits should leave total saving unchanged, a positive coefficient on the differential implies that increases in the differential attract additional resources from the components of the leakage, including the black market for foreign exchange and the return of flight capital.

Also, because of the importance of underground activities, particularly the black market for foreign exchange dealings, the proportion of narrow money (M1) held as currency outside banks (C) is included as an independent variable. This ratio is commonly accepted as a measure of the activity of the informal credit market (Serieux, 1993, and Shaw, 1973). It can also be used to reflect the activities of the black market for foreign exchange and the underground economy (see Hussain, 1996, as example). In our study we followed the latter application of the ratio. Financial saving is negatively related to the proxy measuring the activities of the underground economy, since such activities in the underground economy require large amounts of cash to be held outside the banking system. The first dummy (Dum1) attempts to measure the effects of the shift in financial policies. A significant positive coefficient of this dummy indicates a shift in the savings behaviour following reform. The second dummy (Dum2) is introduced to capture the effects of political instability in the country on financial savings. It is believed that political instability, especially since the 
annulment of the presidential election on June 12, 1993, would negatively affect financial savings.

\subsubsection{The leakage function}

Besides the real interest rate ( $R I R N)$, which measures the opportunity cost of holding money outside the financial system, the leakage function includes the real interest rate differential ( $R I R D)$ and the proxy for measuring the activities of the underground economy $(C / M 1)$ as well as the exchange rate of Naira $(E R)$. The leakage $(L E)$ is negatively related to the real interest rate, since an increase in the real interest rate would increase the opportunity cost of holding money outside the formal financial system. The differential real interest rate is positively related to the leakage. As economic agents try to maximize their gains, they will prefer to save their funds where returns are highest, all thing being equal. Hence, lower domestic compared to foreign real interest rates would lead to increase in capital flight as economic agents seek to maximize their gains. Similarly, the leakage is positively related to the proxy measuring the activities of the underground economy and the exchange rate ${ }^{3}$. Also, the political instability will lead to increase in the leakage, while financial reform is expected to reduce the leakage.

\subsubsection{Total national savings function}

It is hypothesized that real national savings $\left(G N S_{t}\right)$ is positively related to real income ( $R G D P)$, based on Keynes absolute income hypothesis. The other variables incorporate relevant non-Keynesian theories of saving behaviour. For instance, the inflation differential between Nigeria and the United States of America (INFD), a proxy for macroeconomic instability, is introduced on the assumption that the higher the macroeconomic instability the lower the domestic savings will be. Lastly, the real interest rate (RIRN) is introduced. However, whether total saving is positively or negatively related to the real interest rate, will depend on the relative strength of the income and substitution effects of changes in the rate of interest (Warman \& Thirlwal, 1994). The dummies are expected to have effects similar to that on financial savings, except that the channel of effect for political instability on domestic savings is through its effect on domestic income.

\subsection{Econometric procedures}

In this study we employed cointegration and vector error correction using the Johansen (1991) approach. This is preferred to the Engle-Granger (1987) approach because the latter is based on the assumption that there exists only one cointegrating vector that connects the cointegrated variables. Under the 
assumption of one cointegrating vector, OLS estimation applicable to the cointegrating equation will give consistent estimates (Seddighi et al., 2000). However, as argued by Seddighi et al. (2000: 297), in the case where there is more than one cointegrating vector the Engle-Granger methodology is no longer valid, because it produces inconsistent estimates. Since our models are multivariate, there is a likelihood of having more than one cointegrating vector.

In implementing the Johansen methodology, we followed the "general to specific" modeling framework as suggested by Hendry et al. ${ }^{4}$ as against the "specific to general" traditional approach. The "general to specific" framework has become increasingly popular since the 1990s. The framework starts with the specification of a very general model with over-parameterization and then, using different tests, reduces the model to the most parsimonious one. Specifically, we followed the 8-step procedure outlined in Seddighi et al. (2000: 303-5). The estimation begins with unit root tests to confirm that all the variables of the model are suitable to be included for cointegration. The next step is to formulate and estimate the appropriate VAR model. Thereafter, suitable trace tests and maximum Eigenvalue tests can be undertaken to identify the number of cointegrating vectors in the model. Then, the long-run estimation (cointegrating regression) is obtained from the normalized coefficients of the model generated from the cointegrating vector. Lastly, the short run VECM is estimated. For the sake of space, we do not fully discuss the steps here, however, some of the relevant issues involved in the steps are highlighted (interested readers are directed to Seddighi et al., 2000).

\subsubsection{Testing for unit root}

In testing for unit root the most commonly used methods in the literature are the Dickey-Fuller (DF); Augmented Dickey-Fuller (ADF) and the Phillip-Perron (PP). Though these methods have been criticized for their low power and size distortions ${ }^{5}$ they have continued to be routinely used in most analyses due to their availability in most econometrics software packages. In this study, we also employ the DF and ADF for this obvious reason.

Several authors have presented sequential procedures within the "general to specific" framework for testing unit roots if the data generating process (DGP) is not known (see Holden \& Perman, 1994 and Enders, 1995) ${ }^{6}$. A modified mixture of these sequential procedures is also outlined in Seddighi et al. (2000: 274-75). Two issues are, however, of concern to us, here namely: (1) determining the appropriate lag length of the differenced term, and (2) determining the DGP or what is often referred to as conditional hypothesis testing in unit root tests. We briefly describe the methods used in this study below. 
Given an ADF model as follows:

$$
\Delta X_{t}=\alpha+\beta t+\delta X_{t-1}+\sum_{j-2}^{q} \delta_{j} \Delta X_{t-j}+\varepsilon_{t}
$$

where $\Delta$ is the difference operator, $\alpha$ is the constant term or the drift, $\beta$ is the linear deterministic trend (or time trend) and $\mathrm{t}$ is time, and $\varepsilon$ is a white noise error term. Equation (4) is the ADF, but when the difference term in the right hand side (RHS) is not included, the ADF reduces to a DF model. In either case, the series is said to be stationary if the coefficient $\delta=0$ using the $\tau$ statistic $^{7}$. The first problem relates to whether the $\alpha$ and/or $\beta$ in the model is individually significant. This is the test of conditional hypothesis for unit root. Dickey and Fuller (1981) provided three symmetric critical $\tau_{i j}$ values ${ }^{8}$ called $\tau_{\alpha p}, \tau_{\alpha \beta}$ and $\tau_{\alpha p}$, for testing the drift parameter $\alpha$ and the linear trend parameter $\beta$, conditionally upon $\delta=0$. These conditional hypotheses are the following:

(a) Using equation (4) without the difference term:

$\mathrm{H}_{0}: \alpha=0$ given that $\delta=0$, if $|t|<\left|\tau_{\alpha p}\right|$

$\mathrm{H}_{\mathrm{a}}: \alpha \neq 0$ given that $\delta=0$, if $|t|>\left|\tau_{\alpha p}\right|$

(b) Using equation (4) without the difference term:

$\mathrm{H}_{0}: \beta=0$ given that $\delta=0$, if $|t|<\left|\tau_{\alpha \beta}\right|$

$\mathrm{H}_{\mathrm{a}}: \beta \neq 0$ given that $\delta=0$, if $|t|>\left|\tau_{\alpha \beta}\right|$

(c) Using equation (4) without the difference and the linear trend terms:

$\mathrm{H}_{0}: \alpha=0$ given that $\delta=0$, if $|t|<\left|\tau_{\alpha p}\right|$

$\mathrm{H}_{\mathrm{a}}: \alpha \neq 0$ given that $\delta=0$, if $|t|>\left|\tau_{\alpha p}\right|$

Seddighi et al. (2000).

The second problem relates to finding the proper number of the differenced terms to be included in equation (4). Two criteria are used in this study. These are: Schwarz (SIC) and Akaike (AIC), and they are information criteria based on the minimization of an objective function. In model selection the principle is that the smaller the value of the information criteria, the better the model. Comparing the two criteria, the Schwarz is more restrictive than the Akaike (DeSerres \& Guay, 1995). Also, Shibata (1976) has shown that, for a univariate finite order AR process, AIC asymptotically overestimates the order with positive probability, whereas Schwarz provides a consistent estimator asymptotically with probability 1 . These results are also valid in a VAR case (DeSerres \& Guay, 1995). In our analysis, therefore, where there are conflicting results between the two methods, we based our decision on the Schwarz criterion. 


\subsubsection{The cointegrating system}

The Johansen procedure applies maximum likelihood to the VAR model, assuming that the errors are white noise (Maddala \& Kim, 1998). Typically, the general infinite VAR representation is

$$
\Delta X_{T}=\Pi X_{T-1}+\sum_{t=i}^{\infty} B_{I} \Delta X_{t-i}+\rho Z_{t}+\varepsilon_{t}
$$

where $X_{t}$ is a vector of $I(1)$ variables, $\Delta X_{t}$ are all $I(0)$ and $\Pi=0$ if there is no cointegration, and $z_{t}$ is a vector of deterministic variables. However, to estimate the system, we need to fit a finite autoregression of order $k$ :

$$
\Delta X_{T}=\Pi X_{T-1}+\sum_{t=i}^{k} B_{I} \Delta X_{t-i}+\rho z_{t}+\varepsilon_{k t}
$$

Since $\Delta X_{t} \ldots \Delta X_{t-k+1}$ are all $I(0)$ but $X_{t}$ is $I(1)$, in order that this equation is consistent, $\Pi_{i}$ should not be of full rank. Let its rank be r. Then we have:

$$
\Pi_{i}=\alpha \beta^{\prime}
$$

Where $\alpha$ is an $n \times r$ matrix and $\beta^{\prime}$ is an $r \times n$ matrix. Then $\beta^{\prime} X_{t-1}$ are the $r$ cointegrated variables, $\beta$ is the matrix of coefficients of the cointegrating vectors and $\alpha$ has the interpretation of the matrix of error correction terms ${ }^{9}$. In estimating equation (6) one needs to determine the appropriate order $(k)$ of the VAR. In our analysis we used three criteria to do this. The first two are the Schwarz and Akaike information criteria, as discussed above. Next, we consider a sequential test for the significance of the coefficients on lags. The commonly used sequential tests are the Wald statistic and the LR statistic (DeSerres \& Guay, 1995). We employed the likelihood ratio (LR) test, which depends on the usual likelihood ratio statistic given by:

$$
L R=(T-c(k))|\ln | \Omega_{p}|-\ln | \Omega_{j}|| \sim X^{2}\left(n^{2}(p-j)\right)
$$

where $c(k)$ is a correction factor equal to the number of variables in each unrestricted equation in the VAR, $T$ is the number of observations, $n$ is the number of estimated parameters in the VAR, $\ln \left|\Omega_{p}\right|$ is the log of likelihood of the complete coefficients (unrestricted equation) and $\ln \left|\Omega_{j}\right|$ is the $\log$ of likelihood of the smaller coefficients (restricted) equation. While $n^{2}(p-j)$ is the number of restrictions imposed (DeSerres \& Guay, 1995).

Assuming the coefficients of a VAR $(\mathrm{k})$ model, the corresponding lagged variables are given by the matrix $A=\left(A_{1}, A_{2} \ldots A_{k}\right)$. The test works by testing in 
a sequence, the following hypotheses, starting from a large assumed lag length $\mathrm{k}$.

$$
\begin{aligned}
& H_{O}: A_{k}=0 v s H_{a}: A_{k} \neq 0 \\
& H_{0}: A_{k-1}=0 v s . H_{a}: A_{k-1} \neq 0 \text { given that } A_{k}=0 \\
& H_{0}: A_{k-2}=0 v s H_{a}: A_{k-2} \neq 0 \text { given that } A_{k}=A_{k-1}=0 \\
& \ldots \\
& H_{0}: A_{1}=0 v s . H_{a}: A_{1} \neq 0 \text { given that } A_{k}=A_{k-1}=\ldots=A_{2}=0
\end{aligned}
$$

The test stops when a null hypothesis is rejected using the LR statistic and the VAR order $q$, for $k \geq q \geq 1$, is selected accordingly (Holden \& Perman, 1994; and Seddighi et al., 2000).

Using the appropriate lags, the VAR model is estimated, which we then used to test for the rank of cointegration. In order to obtain the cointegrating relations, we adopted the normalization performed by E-Views, but first we arranged the variables such that the dependent variable comes first. We also explored the five deterministic trend assumptions. However, our final decision on deterministic variables to include was based on our findings from the unit root tests, in which case, if some of the series have an intercept and/or a trend, then we include the intercept and/or trend terms in the VAR model. This principle was also followed in our VECM.

\section{EMPIRICAL RESULTS}

\subsection{Unit root results}

As noted earlier, the analysis begins with the testing of each variable for a unit root. The results are presented in Table 2. For each variable we reported the results of the tests for the conditional hypotheses, whether the variable has a drift and/or a deterministic trend, the value at which the null hypothesis for unit root was rejected and the corresponding test level (whether the variable was in level or first difference form), and the appropriate lag length at which the AIC and SIC criteria were satisfied with their corresponding values. Lastly, the table contains the relevant Durbin-Watson statistic and the order of integration I (d) of each variable.

As can be seen from Table 2, all the variables are first difference stationary, that is, they are I(1), except for the inflation variables which are I(0). The fact that inflation variables are stationary is not surprising since they are rate of changes in CPIs, which means they have been differenced already. Of all the variables, 
only the log of real GDP contains a significant positive drift. Similarly, the real interest rate (deposit) in Nigeria has a significant positive trend. Thus, apart from these two cases, we could not reject the conditional hypotheses as specified earlier. The variables also reflect different lag lengths ranging from zero lag to three lags. The reported lags correspond to the values where the two information criteria were at a minimum.

Table 2 Unit root result

\begin{tabular}{|l|c|c|c|c|c|c|c|c|c|c|}
\hline Variable & Trend & Drift & $\begin{array}{c}\text { Station } \\
\text { ary }\end{array}$ & Level & $\begin{array}{c}\mathbf{1}^{\text {st }} \\
\text { diff }\end{array}$ & D.W & AIC & SC & $\begin{array}{c}\text { Lag } \\
\text { diff }\end{array}$ & $\begin{array}{c}\text { Order } \\
\text { of integ }\end{array}$ \\
\hline \multicolumn{1}{|c}{$\mathbf{1}$} & $\mathbf{2}$ & $\mathbf{3}$ & $\mathbf{4}$ & $\mathbf{5}$ & $\mathbf{6}$ & $\mathbf{7}$ & $\mathbf{8}$ & $\mathbf{9}$ & $\mathbf{1 0}$ & $\mathbf{1 1}$ \\
\hline LNRFS & $\mathrm{X}$ & +3 & -4.945 & & 3 & 1.981 & -2.55 & -2.48 & 1 & 1 \\
\hline $\begin{array}{l}\text { LNRGN } \\
\text { S }\end{array}$ & $\mathrm{X}$ & $\mathrm{X}$ & -8.311 & & 3 & 2.029 & 3.95 & 3.98 & 0 & 1 \\
\hline RIRN & +3 & $\mathrm{X}$ & -11.2 & & 3 & 2.088 & 6.51 & 6.57 & 1 & 1 \\
\hline LNRLE & $\mathrm{X}$ & $\mathrm{X}$ & -6.893 & & 3 & 1.976 & 1.811 & 1.842 & 0 & 1 \\
\hline INFD & $\mathrm{X}$ & $\mathrm{X}$ & -3.979 & 3 & & 1.99 & 6.54 & 6.57 & 0 & 0 \\
\hline INFD & $\mathrm{X}$ & $\mathrm{X}$ & -8.771 & & 3 & 1.998 & 6.359 & 6.45 & 2 & 1 \\
\hline ER & $\mathrm{X}$ & $\mathrm{X}$ & -8.275 & & 3 & 2.007 & 7.557 & 7.587 & 0 & 1 \\
\hline RIRD & $\mathrm{X}$ & $\mathrm{X}$ & -2.679 & 3 & & 2.022 & 6.49 & 6.62 & 3 & 0 \\
\hline RIRD & $\mathrm{X}$ & $\mathrm{X}$ & -10.8 & & 3 & 2.056 & 6.577 & 6.638 & 1 & 1 \\
\hline C/M1 & $\mathrm{X}$ & $\mathrm{X}$ & -11.07 & & 3 & 2.051 & - & - & 0 & 1 \\
\hline $\begin{array}{l}\text { LNRGD } \\
\text { P }\end{array}$ & $\mathrm{X}$ & +3 & -4.683 & & 3 & 2.007 & 1.065 & 1.187 & 2 & 1 \\
\hline
\end{tabular}

Note: The values reported as stationary are the values at which the hypothesis of unit root was rejected with the ADF test at 1 per cent level of significance.

\subsection{Cointegration analysis and long-run relationships}

The VAR models estimated correspond with equations (1), (2) and (3) separately. For equation (1), the financial saving function, the VAR model consists of five variables, namely: log of real financial savings (ln RFS ), log of real income $(\ln R G D P)$, real interest rates in Nigeria $(R I R N)$, real interest rate differential (RIRD) and the ratio of currency held outside banks to M1 (C/M1). The dummy variables were not included at this stage, because we felt that they will most likely affect the short run relationship between these variables. In the leakage function, the VAR model also has five variables, viz: the log of real leakage ( $\ln R L E$ ), real interest rate in Nigeria ( $R I R N)$, exchange rate $(E R)$, the real interest rate differential ( $R I R D$ ) and the ratio of currency held outside bank to M1 ( $C / M 1)$. While in the third model, the GNS function, four variables were 
included in the VAR. These are, real interest rate in Nigeria (RIRN), inflation differential between Nigeria and the United State of America (INFD), and the $\log$ of real income $(\ln R G D P)$.

The estimation of each model was carried out using the E-Views in version 3.1. The lag length selection procedures used are the general to specific rule and the two information criteria, Schwarz (SIC) and the Akaike (AIC) as explained above. In estimating the models we experimented with the five deterministic trend assumptions as indicated in E-views ${ }^{10}$. Table 3 below reports the number of cointegrating vectors corresponding to the different lag lengths and the fourth assumption for two of the models.

In the financial savings function two lag lengths, one and five, were chosen on the basis of the diagnostic tests. On the basis of the SIC criterion, one lag was chosen, while the other two led to the choice of five lags. As noted earlier, the choice of a particular assumption should depend to a large extent on the DGP of the series involved. Thus, since in our unit root test results, two variables, $\ln R G D P$ and RIRN possessed a positive drift and deterministic trend, respectively, we run the cointegration test using assumption 4 , that is, we assumed that both series $\mathrm{X}$ and the cointegrating equations have linear trends. This seems to be justified, since macroeconomic variables have a tendency to increase over time. Corresponding to the lag length one, the test indicates one cointegrating relation, while five lags indicate at least two cointegrating relations.

Table 3 Johansen cointegration test

\begin{tabular}{|l|cc|c|}
\hline Variable & \multicolumn{2}{|c|}{$\begin{array}{c}\text { No. of lag length by } \\
\text { selection criteria }\end{array}$} & $\begin{array}{c}\text { No. of Cointegrating } \\
\text { vectors by lag length }\end{array}$ \\
\hline LNRFS & AIC & 5 & 2 \\
& SIC & 1 & 1 \\
& LR & 5 & 2 \\
\hline LNRLE & AIC & 4 & 1 \\
& SIC & 1 & 0 \\
& LR & 4 & 1 \\
\hline LNGNS & AIC & 4 & 1 \\
& SIC & 1 & 1 \\
& LR & 1 & 1 \\
\hline
\end{tabular}

Note: The numbers of cointegrating vectors were determined on the basis of the trace statistic, and the hypothesis of no cointegration rejected at a 5 per cent significance level 
In the case of the leakage function, the diagnostic tests led to the choice of four lags. The cointegration test based on assumption three ${ }^{11}$, indicates only one cointegrating relation (Table 3). The diagnostic test in the third VAR model (the gross national saving function) resulted in the choice of two lag lengths, one and four lags. The test was based on assumption four, since two of the variables, $\ln R G D P$ and RIRN, have a drift and trend respectively. Also, for this model one cointegrating vector was found.

\subsubsection{The cointegration regression}

The results of the cointegrating regressions, that is, the long-run relationships are presented in Table 4. These were obtained from the first normalized coefficients associated with the unique cointegrating vector.

\subsubsection{Financial savings}

One normalized equation of the financial savings function is reported in Table 4. The model performed well in terms of the expected signs and significance of the variables ${ }^{12}$. The income elasticity in this model is positive and significant at 5 per cent. Its magnitude is also high, showing that financial saving has a highincome elasticity. The RIRD has a significant negative coefficient. This coefficient shows that holding other things constant, financial savings changes by about 25 per cent for every one per cent change in the differential of real interest rates between Nigeria and the United State of America. The negative coefficient implies that a higher real interest rate in the United States of America, will lead to an increase in the components of the leakage, including the black market for foreign exchange and capital flight. The coefficient of the RIRN shows that, holding other factors constant, a one per cent increase in the interest rate will lead to a 20 per cent increase in financial savings. The coefficient was significant at 10 per cent, which lends support to the liberalization argument. The proxy measuring the activities of the underground economy has the expected negative sign although the coefficient is not significant.

\subsubsection{The leakage}

As expected, the leakage is negatively related to the RIRN, but positively related to the RIRD and the proxy measuring the activities of the underground economy. The coefficient of the RIRN implies that a one per cent increase in the real interest rate will lead to an approximately 17 per cent leakage reduction. Importantly, however, this result is not significant at the standard levels of significance. The coefficient on the proxy for underground economy was significant at 1 per cent. The coefficient of RIRD was also significant, but at 5 
per cent. The results show that there is a long-run relationship between the leakage, the proxy for the underground economy and the RIRD. The coefficient of the exchange rate has a negative sign, but was not significant. As noted earlier this may be due to the fact that the official exchange rate does not often reflect the prevailing rates.

\subsubsection{Total domestic savings}

Two of the normalized equations of the total domestic savings model are reported in Table 4. The first was based on the VAR of order one, while the second was based on the VAR of order four. The first performed better in terms of the expected signs and significance of the parameters. Real income proves to be the most important determinant of total domestic savings, dominating the equation with a large coefficient and very high t-ratio, significant at 5 per cent. The estimated income elasticity of total domestic savings is very large. This large income elasticity of saving suggests a rising ratio of total domestic saving to income over the long term. The coefficient of the INFD, which measures overall macro-economic stability/instability, is negative and highly significant. A one per cent increase in the differential, keeping other things constant, causes total domestic savings to fall by about 49 per cent. The coefficient of the RIRN is positive, in line with the financial liberalization argument, but the coefficient is small in magnitude and statistically insignificant.

\subsection{The VECM results}

Based on the numbers of the cointegrating vectors and their corresponding lags obtained in the earlier stage, the VECMs for each of the models (Financial Savings, Leakage and Total Domestic Savings) were estimated. The deterministic trend assumptions used are the same as the ones employed in the cointegration regression, and they were based on the presumed DGP, as explained above. The summary of the results is presented in Table 5. In this brief analysis we focus on the coefficients of the dummies.

As shown in Table 5, the dummies in most of the models have the expected signs, but often were not significant. The dummy for financial reforms (Dum1) in the financial savings function was positive in the two specifications. However, it was only significant at 5 per cent when the model with two cointegrating vectors and five lags was employed. The coefficient of the second dummy (representing the effect of political instability on financial saving) shows, as expected, that political instability in the economy affected financial savings negatively. It was, however not significant at the standard levels. 
Table 4 Cointegration regressions: LNRSTFS; LNRLE; \& LNGNS

\begin{tabular}{|c|c|c|c|c|c|c|c|c|c|c|}
\hline $\begin{array}{l}\text { DEP } \\
\text { VAR }\end{array}$ & LAG & $\bar{C}$ & TREND & C/M1 & RIRD & LNRGDP & RIRN & $\overline{\text { ER }}$ & INFD & $\overline{\mathbf{L L}}$ \\
\hline LNRFS & 1 & 9.615 & $\begin{array}{c}0.0299 \\
(2.295)^{* *}\end{array}$ & $\begin{array}{l}-1.29942 \\
(-0.2055)\end{array}$ & $\begin{array}{l}-0.2509 \\
(-2.543)^{* *}\end{array}$ & $\begin{array}{l}3.1002 \\
(2.711)^{* *}\end{array}$ & $\begin{array}{l}0.2036 \\
(1.9306)^{*}\end{array}$ & & & -242.55 \\
\hline LNRLE & 4 & 28.81 & & $\begin{array}{l}6.2178 \\
(5.013) * *\end{array}$ & $\begin{array}{l}0.21514 \\
(2.455)^{* *}\end{array}$ & & $\begin{array}{l}-0.1756 \\
(-1.7564)\end{array}$ & $\begin{array}{c}-0.014 \\
(-0.49)\end{array}$ & & -327.29 \\
\hline LNGNS & 1 & 28.65 & $\begin{array}{l}-0.039 \\
(-1.28)\end{array}$ & & & $\begin{array}{l}6.6713 \\
(2.239)^{* *}\end{array}$ & $\begin{array}{l}0.2772 \\
(1.6941)\end{array}$ & & $\begin{array}{l}-0.489 \\
(-2.546) * *\end{array}$ & -531.79 \\
\hline LNGNS & 2 & 87.74 & $\begin{array}{l}-0.0278 \\
(-0.699)\end{array}$ & & & $\begin{array}{l}17.916 \\
(2.238) * *\end{array}$ & $\begin{array}{l}-0.1145 \\
(-0.553)\end{array}$ & & $\begin{array}{l}-0.5861 \\
(-2.077) * *\end{array}$ & -503.08 \\
\hline
\end{tabular}

Note: ** significant at 5 per cent level and * significant at 10 per cent level. Values in parenthesis are the t-value. 
Table 5 Vector error correction model- $\ln R F S, \ln R L E \quad$ and $\ln R G N S$

\begin{tabular}{|l|c|c|c|c|c|}
\hline \multicolumn{1}{|c|}{ Variable } & $\ln R F S$ & $\ln R F S$ & $\ln R L E$ & $\ln R G N S$ & $\ln R G N S$ \\
\hline Model & 1 & 2 & 3 & 4 & 5 \\
\hline ECM1 & -0.0879 & -0.3359 & -0.0057 & -0.1277 & -0.369 \\
& $(-3.965)^{\mathrm{a}}$ & $(-3.119)^{\mathrm{a}}$ & $(-1.711)^{\mathrm{c}}$ & $(-2.962)^{\mathrm{a}}$ & $(-3.991)^{\mathrm{a}}$ \\
\hline ECM2 & & -0.0065 & & & \\
& & $(-1.20)$ & & & \\
\hline C & -0.069 & 0.1262 & -0.4859 & -0.3878 & -0.362 \\
& $(-1.133)$ & $(1.361)$ & $(-2.023)^{\mathrm{b}}$ & $(-0.997)$ & $(-0.981)$ \\
\hline Dum1 & 0.00112 & 0.2683 & -0.7588 & 0.3628 & 0.0276 \\
& $(0.014)$ & $(2.387)^{\mathrm{b}}$ & $(-0.961)$ & $(0.708)$ & $(0.059)$ \\
\hline Dum2 & -0.0872 & -0.0551 & 0.7243 & 0.4567 & 0.575 \\
& $(-0.035)$ & $(-0.469)$ & $(2.332)^{\mathrm{b}}$ & $(0.921)$ & $(1.178)$ \\
\hline Adj.R ${ }^{2}$ & 0.3912 & 0.5487 & 0.0435 & 0.1307 & 0.2601 \\
\hline F-Statistic & 6.7826 & 3.8508 & 1.1425 & 1.165 & 1.641 \\
\hline
\end{tabular}

Note A significant at 1 per cent; b significant at 5 per cent; and c significant at 10 per cent. Model 1 used one lag; model 2 used five lags; model 3 used four lags; model 4 used one lag and model 5 used four lags. Values in parenthesis are the t-value.

The coefficients of the dummies had the appropriate signs in the leakage function indicating that financial reforms negatively affect the leakage while political instability encourages the leakage, although it was only the coefficient of the political instability dummy that was significant (at 5 per cent). Thus, it is apparent that, while financial reforms have the potential to reduce the leakage from the formal financial system, a desired result can only be achieved if there is stable political and macroeconomic environment. Finally, the coefficients on the dummies in the case of total domestic savings did not behave in line with expectations, and importantly, were not significant.

\section{POLICY IMPLICATIONS OF THE RESULTS AND CONCLUSIONS}

The results indicate that, with regards to currency substitution, both the real interest rate and the interest rate differential are important. Increasing financial saving and reducing the leakage from the formal financial sector will require not only an increase in the real interest rate on domestic currency deposits, but also the maintenance of the real interest rate on domestic currency deposits which are higher than the real return on foreign currency deposits and the expected real return on foreign assets. High real interest rates, however, might attract 
excessive capital inflows, jeopardize monetary control and discourage investment (Hussain, 1996). Also, given the important role of macroeconomic and political stability in the process of savings mobilization, it is important that the achievement of these should be a matter of priority.

Over the short term, where macroeconomic and political stability are given high priority, improving the efficiency of investment and enhancing investment by increasing the maturity of loanable funds may check the negative effects of high interest rates. In the medium to long term and following the restoration of macroeconomic and political stability, the interest rates might be allowed to fall gradually. The appropriate interest rate would not discourage investment or encourage currency substitution and capital flight.

In addition to a prudent interest rate policy, the dangers of expanding the leakage (and its components) can be averted through the development of a capital market and the propagation of alternative financial vessels such as stocks, corporate bonds and government securities. These financial vessels will provide good alternatives to holding foreign fiat money and allow savers to diversify their portfolios and minimize their risk of holding financial assets denominated in domestic currency. However, such measures must be combined with macroeconomic policies that tend to create a stable economic environment and adopt appropriate financial and exchange rate policies in order to reduce the incentives for economic agents to prefer foreign denominated assets to domestic currency assets. This is because, under such policies, inflation rates, exchange rate depreciation, and interest rate instability will be minimized while the growth of real income will be stable.

\section{ENDNOTES}

1 The authors would like to thank the two anonymous referees of this paper for their valuable comments. They are also grateful to Mr David Croome for his useful comments on the initial version of this paper. In addition, comments by participants at the $8^{\text {th }}$ Annual Conference of the African Econometrics Society have been very useful in revising the paper. However, the usual disclaimer applies.

2 El-Evian (1988) is a comparative study of Egypt and Yemen Arab Republic.

3 The black market premium (the difference between the black market and official exchange rate should be the most appropriate here, and it should be positively related to the leakage. The difficulty of obtaining reliable data on the black market rate compels us to use the official rate.

$4 \quad$ See Hendry and Mizon (1978), Hendry and Richard (1982, 1983). 
5 See Maddala and Kim (1998), chapter four, for a detailed discussion of these and other problems relating to these testing methods for Unit Roots.

6 The interested reader may consult the latter reference for details.

$7 \quad$ Both Dickey and Fuller (1979) and Mackinnon (1991) have tabulated critical values for the $t_{\delta}$ statistic which they call the ' $\tau$ (tau) statistic, for testing the hypothesis of unit root.

8 The table of these critical values is reproduced in Seddighi et al. (2000: 272).

9 This is Granger's representation theorem.

10 The five deterministic trend assumptions are: (1) Series $X$ has no deterministic trend and the cointegrating equations do not have intercepts; (2) Series $X$ has no deterministic trend and the cointegrating equations have intercepts; (3) Series $X$ has linear trends but the cointegrating equations have only intercepts; (4) Both series X and the cointegrating equations have linear trends; and (5) Series $\mathrm{X}$ has quadratic trends and the cointegrationg equations have linear trends.

11 Preliminary experiments show this assumption to be the most valid one. For instance, the coefficient of the trend variable was insignificant. This is also in harmony with unit root tests, which indicate that all the variables in the model, except RIRN, are without a constant or a deterministic trend.

12 An alternative model with five lag lengths was also estimated, however, the model did not perform well in terms of the expected signs and the significance of the variables, hence it is not reported here. 


\section{DATA APPENDIX: Data measurement and sources}

The data used for the regression equations are defined and measured as follows: Financial Savings (FS ): This is the sum of savings and time deposits with commercial and merchant banks, the National Provident Fund, Savings at the Federal Savings Bank and the Federal Mortgage Banks and Premium Bonds, Savings Certificates and Savings Stamps. Since saving is a flow, financial savings is measured by the change in the flow of total financial saving, i.e. $\Delta F S$, and then deflated using the consumer price index to obtain the real financial saving for each period. The data for financial savings was obtained from the Central Bank of Nigeria (CBN) Statistical Bulletin. Gross national savings (GNS) is the residual from what is consumed of gross disposable income from the agricultural, industrial, mining and petroleum, retail trade and other sectors of the economy. This is measured in million Naira at 1990 constant prices and was obtained from the CBN Statistical Bulletin. The leakage $(L E)$ is defined as the difference between total savings (GNS) and the financial saving, as measured above, i.e. $\mathrm{LE}=\Delta(\mathrm{GNS}$ - FS $)$.

Real interest rate ( $R I R$ ) is measured as the difference between nominal interest rate and the inflation rate: RIRN and RIRUS represent real in Nigeria and USA respectively. It is expressed as percentage points. The deposit interest rate was used as reported in the IMF International Financial Statistics (IFS). Inflation (INF) is the rate of change in consumer price index (CPI) using 1990 as the base year; it was also obtained from the IFS. The nominal variables were deflated using this index. Inflation differential (INFD) is the difference between inflation rate in Nigeria and the United States of America as a proxy for macroeconomic instability. $C / M 1$ is the ratio of currency held outside banks to M1, a proxy for the underground economy, where $M 1$ is the narrow definition of money (currency plus demand deposits) and were obtained from the IFS. Income is the real GDP at 1990 constant prices from the CBN Statistical Bulletin. Exchange rate is the official nominal exchange rate (Naria/1US\$) as reported in IFS. Dum1 is a dummy variable representing the effects of financial reform, it assumes the value of one for the period 1987 to 1998 and zero otherwise. Dum2 is a dummy variable representing the influence of political instability and it assumes a value of one for the period 1993: 3 to 1998 and zero otherwise. 


\section{REFERENCES}

1 AZIAKPONO, M.J. (1999) "Financial liberalization, currency substitution and savings: A theoretical construct and a survey of evidence”, Journal of Economic Management, 6 (1): 18-26.

2 CENTRAL BANK OF NIGERIA (1993) Perspective of Economic Policy Reforms in Nigeria, A Study Report by Central Bank of Nigeria, Central Bank of Nigeria: Lagos.

3 CENTRAL BANK OF NIGERIA (1998) Statistical Bulletin, 1.9 (2)

4 DESERREA, A. \& GUAY, A. (1995) "Selection of the truncation lag in structural VARs (or VECMs) with long-run restrictions", Working Paper 95-9, Bank of Canada.

5 DICKEY, D. \& FULLER, W.A. (1979) "Distribution of the estimators for autoregressive time series with unit root", Journal of the American Statistical Association, 74: 427-31.

6 DICKEY, D.A. \& FULLER, W.A. (1981) "Likelihood ratio statistics for autoregressive time series with a unit root”, Econometrica, 49: 1057-72.

7 ENDERS, W. (1995) Applied Econometric Time Series, John Wiley: New York.

8 EL-EVIAN, M. (1988) "Currency substitution in Egypt and the Yemen Arab Republic: A comparative quantitative analysis”, IMF Staff Paper, International Monetary Fund: Washington, D.C.

9 GIBSON, H.D. \& TSAKALOTOS, E. (1994) "The scope and limits of financial liberalization in developing countries: A critical survey", Journal of Development Studies, 30 (3): 578-628.

10 HARRIS, R.J.D. (1995) Using Cointegration Analysis in Econometric Modeling, Prentice Hall/Harvester Wheatsheaf.

11 HENDRY, D.F. \& MIZON, G.E. (1978) "Serial correlation as a convenient simplification not a nuisance: A comment on a study of the demand for money by the Bank of England”, Economic Journal, 88: 54963.

12 HENDRY, D. \& RICHARD, J.F. (1982) "On the formulation of empirical models in dynamic econometrics", Journal of Econometrics, 20: 3-33.

13 HENDRY, D. \& RICHARD, J.F. (1983) "The econometric analysis of time series”, International Statistical Review, 51: 111-63.

14 HOLDEN, D. \& PERMAN, P. (1994) "Unit roots and cointegration for the economist" in: Rao B.B., Cointegration for an Applied Economist, Macmillan: London.

15 HUSSAIN, M.N. (1996) "Financial liberalization, currency substitution and investment: The case of Egypt”, Economic Research Papers, No.24. The African Development Bank: Abidjan. 
16 JOHANSEN, S. (1991) "Estimation and hypothesis testing of cointegrated vectors in Gaussian VAR model," Econometrica, 59 (6): 1551-80.

17 LEVINE, R. (1997) "Financial development and economic growth: views and agenda”, Journal of Economic Literature, 35: 688-726.

18 MADDALA S.G. \& KIM, I. (1998) Unit Roots, Cointegration and Structural Change, Cambridge University Press.

19 MCKINNON, R.I. (1973) Money and Capital in Economic Development, Brookings Institution: Washington.

20 MACKINNON, J.G. (1991) Critical Value for Cointegration, Oxford University Press.

21 NISSANKE, M. \& ARYEETEY, E. (1998) Financial Integration and Development: Liberalisation and Reform in Sub-Sahara Africa, Routledge: London and New York.

22 ORESOTU, F.O. (1993) "Implementations of indirect monetary control in Nigeria: Problems and prospects”, CBN Economic and Financial Review, 31 (3) September.

23 ORESOTU, F.O. (1992) "Interest behaviour under a programme of financial reform: the Nigerian case”, CBN Economic and Financial Review, 30 (2) June.

24 RAMIREZ-ROJAS, C.L. (1985) "Currency substitution in Argentina, Mexico and Uruguay” IMF Staff Papers, 32 (4): 629-667.

25 SEDDIGHI, H.R., LAWLER, K.A \& KATOS, V.A. (2000) Econometrics: A Practical Approach, Routledge: London and New York

26 SERIEUX, J. (1993) "Deposit rates, money and price stabilization under structural adjustment: Theory and evidence from Ghana and Kenya", University of Toronto.

27 SHAW, E. (1973) Financial Deepening in Economic Development, Oxford University Press.

28 SHIBATA, R. (1976) "Selection of order of an autoregressive model by Akaike's Information Criterion”, Biometrika, 63: 117-126.

29 WARREN, V. \&. THIRLWAL, A.P. (1994) "Interest rate, savings, investment and growth in Mexico, 1960-1990: Tests of financial liberalization hypothesis", Journal of Economic Development, November.

30 YUSUF, S. \& PETERS, R.K. (1994) "Savings behaviour and its implications for domestic resource mobilization: The case of the Republic of Korea”, World Bank Staff Working Paper, No. 628, The World Bank: Washington D.C. 